\title{
Sistem Pendukung Keputusan Penerima Bantuan Covid-19 Kelurahan Bugel Kota Salatiga Menggunakan Simple Additive Wieghting (Saw)
}

\author{
Ria Saskia Zevanya Warami \\ Program Studi Sistem Informasi, \\ Fakultas Teknologi Informasi, Universitas Kristen Satya Wacana \\ Email:682017130@student.uksw.edu
}

\begin{abstract}
The purpose of this study is to facilitate decision making in providing COVID-19 assistance to underprivileged communities in Bugel Village, Salatiga City. This study uses the Simple Additive Wieghting method or commonly referred to as the weighted addition method. This method performs a weighted summation of the performance ratings of each alternative on all attributes. The results of the study from 5 families showed who was the most eligible to receive the Covid-19 assistance in the Bugel Village, Salatiga City, namely Sardianto with a final normalization result of 0.785 . It is hoped that this research can be used to make decisions quickly and objectively.
\end{abstract}

Keywords: Decision Support System, SAW, Covid-19 Assistance.

\section{PENDAHULUAN}

Pasca merebaknya COVID-19, negara-negara di dunia saat ini sedang menghadapi krisis ekonomi yang parah. Banyak negara di dunia yang memberlakukan penjara sosial atau alienasi fisik untuk menghentikan semua kegiatan ekonomi atau blokade telah menghancurkan banyak negara dalam perekonomian. Di Indonesia, dilaporkan bahwa kebijakan pembatasan sosial berskala besar (PSBB) telah meningkatkan jumlah penduduk miskin. Laporan dari Laboratorium Aksi Kemiskinan Asia Tenggara Abdul Latif Jameel menyebutkan, jumlah pengangguran meningkat sejak Covid-19 menyebar di seluruh wilayah Indonesia. Untuk mengatasi dampak ekonomi ini, pemerintah Indonesia telah menyiapkan dana ratusan miliar rupiah untuk membantu masyarakat yang terkena virus corona baru, terutama kalangan menengah ke bawah. Beberapa program yang dicanangkan pemerintah terbagi menjadi dua jenis, yaitu program non konvensional (4 program) dan program reguler (3 program). 
Journal of Computer and Information Systems Ampera

Vol. 2, No. 1, January 2021 e-ISSN: 2775-2496

https://journal-computing.org/index.php/journal-cisa/index

Proses seleksi yang tidak terbuka menyebabkan sebagian permasalahan di sebagian besar wilayah di Indonesia salah satunya Kelurahan Bugel Kecamatan Sidorejo Kota Salatiga. Diantara kasus tersebut yakni terlambatnya penyaluran dorongan covid- 19 yang sudah dianggarkan tadinya. Keterlambatan tersebut membuat warga yang memerlukan dorongan tersebut terkendala dalam penanganan permasalahan yang dihadapinya. Proses penyeleksian data yang tadinya dicoba secara manual akan diubah dengan proses secara terkomputerisasi. Sistem pendukung keputusan ialah salah satu fitur lunak yang dibesarkan secara eksklusif untuk menunjang dalam pengambilan keputusan. Pada sistem pendukung keputusan penerima bantuan covid- 19 ini bisa menangani kelemahan serta kekurangan dari penerapan pemilihan yang tadinya. Dalam proses system pendukung penerima bantuan covid- 19 pada Kelurahan Bugel nantinya hendak dicoba dengan memakai metode Simple Additive Weighting( SAW).

Keunggulan metode simple additive weighting dibanding dengan sistem pendukung keputusan yang lain terletak pada kemampuannya dalam melakukan penilaan secara lebih tepat karena didasarkan pada nilai kriteria dan bobot tingkat kepentingan yang dibutuhkan dalam metode SAW juga dapat menyeleksi alternative terbaik dari sejumlah alternative yang ada kemudian dilakukan proses perangkingan setelah menentukan nilai bobot untuk setiap atribut [1]. Tujuan dari penelitian ini adalah mempermudah dalam pengambilan keputusan dalam pemberian bantuan covid-19 pada masyarakat kurang mampu di Kelurahan Bugel, serta membangun sistem yang dapat mempermudah bagi pemerintah daerah dalam menentukan calon penerima bantuan yang sesuai dengan program bantuan, sehingga bantuan yang diberikan tepat sasaran. Manfaat dari penelitian ini yaitu yang pertama bagi Kelurahan Bugel sistem yang dihasilkan agar mendukung program bantuan covid-19 ini tepat sasaran dengan memprioritaskan masyarakat yang lebih membutuhkan dilihat dari kriteria-kriteria kelayakan penerima program bantuan covid-19 tersebut.

\section{PENELITIAN TERDAHULU}

Pada tahun 2018, M.Salim menggunakan Metode Simple Additive Weighting untuk mempelajari sistem pengambilan keputusan yang berjudul "Sistem Pendukung Keputusan Pemilihan Penerima Bantuan Perbaikan Rumah Menggunakan Metode Simple Additive Weighting 
https://journal-computing.org/index.php/journal-cisa/index

(SAW)".Pekerjaan, pendapatan, material dinding, kondisi dinding, material atap, kondisi atap, material lantai, kondisi lantai, ukuran rumah, kepemilikan kamar mandi, jumlah penghuni, bantuan yang diterima. Berdasarkan penelitian yang telah dilakukan dapat disimpulkan bahwa Sistem Pendukung Keputusan (SPK) dapat digunakan sebagai bahan pertimbangan dalam memilih dan menentukan calon penerima dana bantuan perbaikan keluarga. Sistem dapat dihitung dan ditampilkan dalam bentuk grafik yang mudah dipahami. Diharapkan penelitian ini dapat digunakan sebagai sarana pengambilan keputusan yang cepat dan objektif[2].

Selanjutnya Pada tahun 2020, F.Sembiring dkk melakukan penelitian dengan sistem pengambilan keputusan dengan menggunakan metode simple additive weighting dengan judul Sistem Pendukung Keputusan Penerima Bantuan Covid 19 menggunakan Metode Simple Additive Weighting (SAW) Studi Kasus : Desa Sundawenang berdasarkan penelitian yang telah dilakukan dapat diambil kesimpulan sebagain berikut Program bantuan sosial pemerintah dalam menghadapi pandemi COVID-19 masih belum efektif karena tidak tepat sasaran. Di masa pandemi ini, semua bantuan sosial harus segera disalurkan menggunakan data yang tersedia. Namun data yang digunakan seringkali tidak akurat, sehingga tidak dapat dihindari bahwa penerima tidak tepat sasaran. Informasi dan pengetahuan tentang jenis dan persyaratan penerima bantuan sosial harus terus dikomunikasikan kepada pejabat kabupaten dan masyarakat. Oleh karena itu, bagi penerima bantuan COVID-19 yang menggunakan sistem pendukung keputusan simple additive weighting (SAW) dengan kriteria yang telah ditentukan, hasil nilai hoax terbesar adalah yang berhak mendapatkan bantuan sosial. Hal ini dapat meminimalisir kecurangan dan membantu semua pihak di desa lebih mudah memiliki kemampuan untuk memilih atau menyeleksi calon penerima bansos, sehingga dapat mencapai tujuannya[3].

Lalu Pada Tahun 2020, Satria dkk melakukan penelitian dengan sistem pengambilan keputusan dengan menggunakan metode Hybrid AHP-SAW studi kasus Desa Makamhaji dengan judul Sistem Pendukung Keputusan Penerima Bantuan Pangan Non Tunai Dengan Metode Hybrid AHP- SAW dengan kriterianya adalah Pendapatan Per Bulan, Tanggungan Keluarga, Pekerjaan, Kepemilikan Rumah, Lantai Rumah, Kepemilikan MCK, Kepemilikan Lahan, Pendidikan KK. Kesimpulan yang dapat diambil dari hasil analisis, perancangan dan pembuatan Sistem Pendukung Keputusan 
Journal of Computer and Information Systems Ampera

Vol. 2, No. 1, January 2021 e-ISSN: 2775-2496

https://journal-computing.org/index.php/journal-cisa/index

Penerima Bantuan Pangan Non Tunai di Desa Makamhaji menggunakan Metode Hybrid AHP - SAW adalah Tercapainya tujuan untuk merancang, membangun, dan mengimplementasikan sistem pendukung keputusan penerimaan bantuan pangan non tunai yang dapat menerapkan semua kriteria yang ada dengan metode Hybrid AHP - SAW. Pada penelitian ini penulis berhasil menerapkan metode AHP untuk menentukan bobot kriteria dan menerapkan metode SAW untuk perangkingan alternatif pada penerima BPNT. Mengimplementasikan fitur - fitur seperti Input data pengguna, Input data penduduk, Input data kriteria tiap-tiap penduduk, perbandingan tiap bobot, serta menghasilkan output berupa data penduduk penerima BPNT[4].

Berikutnya Pada tahun 2020, Yulisman dkk melakukan penelitian dengan sistem pengambilan keputusan dengan menggunakan metode simple additive weighting dengan judul Sistem Pendukung Keputusan Penentuan Penerima Bantuan Rumah Sehat Layak Huni Menggunakan Metode Saw Di Desa Pasir Emas Kecamatan Singingi dengan kriterianya adalah Luas Ruangan, Kondisi Dinding, Kondisi Atap, Kondisi Lantai, Usia, Kepemilikan Tanah, Tanggungan Keluarga, Penghasilan, Lama Bedomisili, Status Perkawinan, Pekerjaan, Kesehatan, Kepemilikan Rumah. Berdasarkan hasil penelitian dan pembahasan sistem pendukung keputusan identifikasi penerima bantuan rumah sehat di Desa Pasir Emas Kecamatan Singingi Kabupaten Singingi Kabupaten Kuantan dapat disimpulkan bahwa sistem pendukung keputusan identifikasi penerima rumah sehat dapat tinggal di Desa Pasir Emas Kecamatan Singingi. Dengan memilah data yang diolah dalam sistem, desa membantu desa untuk menentukan penerima bantuan perumahan yang layak huni. Aplikasi yang dirancang merupakan sistem pendukung keputusan yang digunakan untuk mengidentifikasi penerima bantuan perumahan sehat dan layak huni di Desa Pasir Emas, Kandang. Singi. Dibandingkan dengan sistem saat ini, aplikasi ini dapat memberikan beberapa keuntungan, seperti saat memproses data masyarakat untuk menentukan penerima manfaat lebih cepat[5].

Terakhir Pada tahun 2017, Edi melakukan penelitian dengan sistem pengambilan keputusan dengan menggunakan metode simple additive weighting dengan judul Sistem Pendukung Keputusan Penerimaan Karyawan Dengan Metode Simple Additive Weighting (SAW) dengan kriterianya adalah Pendidikan, Pengalaman Kerja, Penampilan, Test, Wawancara, Usia, Status, Alamat. Berdasarkan hasil penelitian dari perancangan dan pembangunan aplikasi sistem pendukung keputusan 
https://journal-computing.org/index.php/journal-cisa/index

penerimaan karyawan baru di Universitas Muhammadiyah Riau dengan menggunakan metode Simple Additive Weighting (SAW), maka dapat ditarik kesimpulan sebagai berikut Metode Simple Additive Weighting (SAW) mampu menyelesaikan persoalan suatu pemilihan dengan model menggunakan nilai prioritas atau bobot yang ditentukan setiap kebutuhan. Semakin banyak alternatif (calon karyawan baru) dan penggunaan kriteria yang lebih spesifik, maka sistem akan menghasilkan nilai dari proses penyeleksian yang lebih akurat. Metode Simple Additive Weighting (SAW) mampu mendukung keputusan penerimaan karyawan dengan memberikan perangkingan alternatif [6].

\section{METODE PENELITIAN}

Metode penelitian pada dasarnya merupakan cara ilmiah untuk mendapatkan informasi dengan tujuan dan kegunaan tertentu. Metode penelitian merupakan cara yang digunakan oleh peneliti dalam mengumpulkan data penelitiannya. Cara ilmiah berarti kegiatan penelitian ini didasarkan pada ciri-ciri keilmuan yaitu rasional, empiris, dan sistematis. Metode penelitian ini digunakan sebagai pedoman penelitian dalam pelaksanaan penelitian agar hasil yang dicapai tidak menyimpang dari tujuan yang telah ditentukan sebelumnya. Sebelum melakukan penelitian terlebih dahulu peneliti membuat perizinan serta melakukan kontak dengan Informan dan juga menyiapkan bahan penelitian. Perlengkapan yang dibutuhkan dalam penelitian ini adalah menyiapkan subjek penelitian yaitu warga Kelurahan Bugel, dan menyiapkan kuisioner yang berisi pertanyaan-pertanyaan mendukung.

Pada penelitian ini dilakukan di Kelurahan Bugel, Jl. Mutiara No.41, Kecamatan Sidorejo, Kota Salatiga, Jawa Tengah, 50713. Data yang diambil berupa data nama-nama penerima bantuan covid-19. Nama-nama tersebut diberikan oleh pegawai kantor kelurahan. Setelah itu peneliti mewawancarai lima dari nama-nama tersebut untuk dimintai data-data sesuai dengan kriteria. Adapun kriteria yang digunakan adalah Pendapatan/bln, Jumlah Tanggungan, Pekerjaan, Kepemilikan Rumah, Lantai rumah, Kepemilikan Kamar Mandi, Kepemilikan Lahan, Pendidikan KK, Terindikasi Covid 19, Terkena PHK. Semua kriteria diberikan bobot serta presentase. 


\section{Journal of Computer and Information Systems Ampera}

Vol. 2, No. 1, January 2021 e-ISSN: 2775-2496

https://journal-computing.org/index.php/journal-cisa/index

\subsection{Simple Additive Wieghting}

Metode Simple Additive Weighting (SAW) sering dikenal dengan istilah metode penjumlahan terbobot. Konsep dasar metode Simple Additive Weighting (SAW) adalah mencari penjumlahan terbobot dari rating kinerja setiap alternatif pada semua atribut. Metode SAW membutuhkan proses normalisasi matriks keputusan $(\mathrm{X})$ ke suatu skala yang dapat dibandingakan dengan semua rating alternatif yang ada[7].

$$
V_{i}=\sum_{j=1}^{M} w_{j} x r_{i j}
$$

Dimana rij merepresentasikan nilai normalisasi dari attribut serta $V i$ merupakan nilai penjumlahan dari alternatif. Alternatif dengan nilai $P i$ paling tinggi bisa dikira selaku alternatif terbaik[8].

Riset ini memakai tata cara Sederhana Additive Weighting( SAW) buat menghitung serta memastikan urutan penentuan penerima dorongan covid- 19, langkah tata cara Sederhana Additive Weighting( SAW) dalam sistem pendukung keputusan penerima bantuan covid- 19 di Kelurahan Bugel Kota Salatiga:

a. Tentukan kriteria dan alternatif dari data yang diteliti dan buat

b. Masukkan bobot dari setiap kriteria $\mathrm{W}=[W 1, W 2, W 3, \ldots . . W j]$.

c. Tentukan masing masing kriteria apakah termasuk Cost atau Benefit.

d. Susun tabel keputusannya.

e. Normalisasikan bobot dari setiap kriteria berdasarkan Cost atau Benefit.

$$
r_{i j}=\left\{\begin{array}{c}
\frac{x_{i j}}{\max \left(x_{i j}\right)}, j i k a \text { benefit } \\
\frac{\min _{\left(x_{i j}\right)}}{x_{i j}}, j i k a \text { cost }
\end{array}\right.
$$

f. Dengan $(x i j)$ merupakan nilai optimal dari kriteria W tiap alternatif, sertami $x i j)$ merupakan nilai minimun dari kriteria $W$ tiap alternatif.

g. Dan Jumlahkan hasil normalisasi bobot seluruh kriteria $\mathrm{W}$ pada tiap alternative memakai rumus (1) buat memperoleh Vi ataupun nilai akhir normalisasi.

h. Urutkan hasil akhir normalisasi dari yang paling tinggi ke yang terendah. 


\section{Journal of Computer and Information Systems Ampera}

Vol. 2, No. 1, January 2021 e-ISSN: 2775-2496

https://journal-computing.org/index.php/journal-cisa/index

Berikut ini merupakan Gambar I yang meunjukkan langkah langkah dalam tata cara Sederhana Additive Weighting( SAW) dalam berupa flowchart.

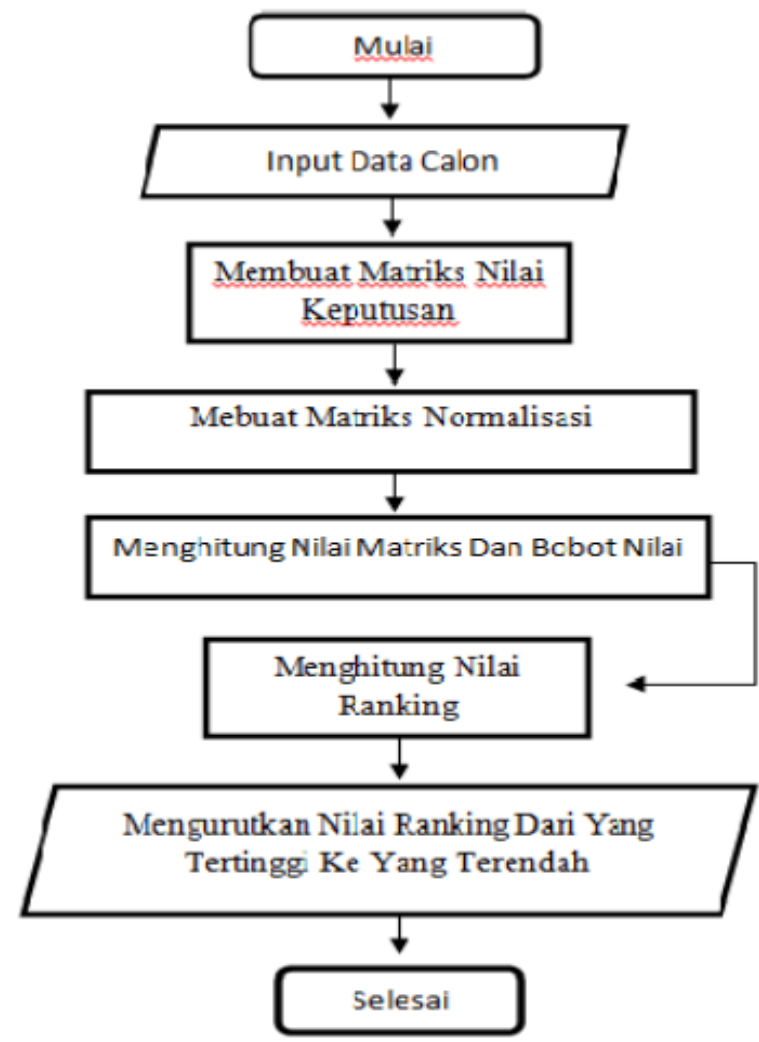

Gambar I. Flowchart Metode SAW[3].

\subsection{Sistem Pendukung Keputusan}

Sistem Pendukung Keputusan adalah bagian dari system informasi berbasis computer yang dipakai untuk mendukung pengambilan keputusan dalam suatu organisasi atau perusahaan. Dapat juga dikatakan sebagai sisitem computer yang mengolah data menjadi informasi untuk mengambil keputusan dari masalah semi terstruktur yang spesifik [9]. Sistem pendukung keputusan ataupun Decission Support System( DSS) ialah sistem yang memproses informasi jadi data yang setelah itu digunakan buat menolong pengguna dalam mengambil keputusan dalam permasalahan tidak terstruktur. Konsep ini dikenalkan oleh Michael S. 


\section{Journal of Computer and Information Systems Ampera}

Vol. 2, No. 1, January 2021 e-ISSN: 2775-2496

https://journal-computing.org/index.php/journal-cisa/index

Scoot pada tahun 1970- an dengan sebutan Management Decision System( Iwan\&amp; Lirien, 2012). Sistem Pendukung Keputusan (SPK) merupakan pelaksanaan dari Multi Attribute Decision Making( MADM). Teknik- teknik MADM difokuskan pada macam apa para pakar ataupun pengambil keputusan menetapkan bobot nilai kriteria bersumber pada rujukan mereka.

\section{PEMBAHASAN}

\subsection{Perhitungan SAW}

Langkah awal yaitu memastikan Alternatif yakni nama kepala keluarga calon penerima bantuan covid- 19 di Kelurahan Bugel Kota Salatiga. Sebaliknya kriteria yaitu kriteria yang dipunyai kepala keluarga tersebut.

a) Berikut ini merupakan tabel alternatif serta serta tabel kriteria. Tabel 1 serta Tabel 2 masing masing menampilkan Alternatif serta Kriteria yang digunakan dalam riset ini.

Tabel 1. Alternatif

\begin{tabular}{cc}
\hline No. & Alternatif (Ai) \\
\hline & \\
1. & Sutrisno \\
2. & Darwin Peru \\
3. & Sardianto \\
4. & Muhtarom \\
5. & Kasmun \\
\hline
\end{tabular}

Tabel 2. Kriteria

\begin{tabular}{ccc}
\hline No & Alternatif (Ai) & Simbol \\
\hline 1. & Pendapatan/bln & C1 \\
2. & Jumlah Tanggungan & C2 \\
3. & Pekerjaan & C3 \\
4. & Kepemilikan Rumah & C4 \\
5. & Lantai rumah & C5 \\
6. & Kepemilikan Kamar Mandi & C6 \\
7. & Kepemilikan Lahan & C7 \\
8. & Pendidikan KK & C8 \\
9 & Terindikasi Covid 19 & C9
\end{tabular}




\section{Journal of Computer and Information Systems Ampera}

Vol. 2, No. 1, January 2021 e-ISSN: 2775-2496

https://journal-computing.org/index.php/journal-cisa/index

\begin{tabular}{lll}
\hline 10 & Terkena PHK & C10 \\
\hline
\end{tabular}

b) Langkah berikut memastikan bobot(n) dan bobot presentase dari tiap kriteria. Dibawah ini merupakan tabel 3sampai tabel 13 yang menunjukan bobot presentase dari tiap krieria.

Tabel.3 Bobot $n 1$

\begin{tabular}{ccc}
\hline No. & Pendapatan (C1) & Bobot (n1) \\
\hline 1. & $0-1,2$ Juta & 4 \\
2. & $1,3-1,8$ Juta & 3 \\
3. & 1,9-2,1 Juta & 2 \\
4. & 2,2 Juta keatas & 1 \\
\hline
\end{tabular}

Table.4 Bobot $n 2$

\begin{tabular}{ccc}
\hline No. & Jumlah Tanggungan (C2) & Bobot (n2) \\
\hline 1. & $>=4$ Anak & 5 \\
2. & 3 Anak & 4 \\
3. & 2 Anak & 3 \\
4. & 1 Anak & 2 \\
\hline
\end{tabular}

Table.5 Bobot n3

\begin{tabular}{ccc}
\hline No. & Pekerjaan (C3) & Bobot (n3) \\
\hline 1. & Tidak Bekerja & 4 \\
2. & Buruh / Tani / Lainya & 3 \\
3. & Karyawan Swasta & 2 \\
4. & Wiraswasta / Pedagang & 1 \\
\hline
\end{tabular}

Table. 6 Bobot $n 4$

\begin{tabular}{ccc}
\hline No. & Kepemilikan Rumah (C4) & Bobot (n4) \\
\hline 1. & Menumpang & 5 \\
\hline
\end{tabular}




\section{Journal of Computer and Information Systems Ampera}

Vol. 2, No. 1, January 2021 e-ISSN: 2775-2496

https://journal-computing.org/index.php/journal-cisa/index

\begin{tabular}{lcc}
\hline 2. & Sewa & 3 \\
3. & Milik Sendiri & 1 \\
\hline
\end{tabular}

Table. 7 Bobot $n 5$

\begin{tabular}{ccc}
\hline No. & Lantai Rumah (C5) & Bobot (n5) \\
\hline 1. & Tanah & 4 \\
2. & Kayu & 3 \\
3. & Semen & 2 \\
4. & Keramik & 1 \\
\hline
\end{tabular}

Tabel.8 Bobot n6

No. Kepemilikan Kamar Mandi Bobot (n6)

(C6)

\begin{tabular}{lcc}
\hline 1. & Tidak Ada & 4 \\
2. & Milik Sendiri & 1 \\
\hline
\end{tabular}

Table 9. Bobot $\mathrm{n} 7$

\begin{tabular}{ccc}
\hline No. & Kepemilikan Lahan (C7) & Bobot (n7) \\
\hline 1. & Tidak Punya & 4 \\
2. & Punya & 1 \\
\hline
\end{tabular}

Tabel 10. Bobot n8

\begin{tabular}{ccc}
\hline No. & Pendidikan KK (C8) & Bobot (n8) \\
\hline 1. & Tidak Sekola & 5 \\
2. & SD & 4 \\
3. & SMP & 3 \\
4. & SMA & 2 \\
5. & $>=D 1$ & 1 \\
\hline
\end{tabular}




\section{Journal of Computer and Information Systems Ampera}

Vol. 2, No. 1, January 2021 e-ISSN: 2775-2496

https://journal-computing.org/index.php/journal-cisa/index

Tabel.11 Bobot $n 9$

\begin{tabular}{ccc}
\hline No. & Terindikasi (C9) & Bobot (n9) \\
\hline 1. & Ada & 4 \\
2. & Tidak Ada & 1 \\
\hline
\end{tabular}

Table.12 Bobot $\mathrm{n} 10$

\begin{tabular}{ccc}
\hline No. & Terkena PHK (C10) & Bobot (n10) \\
\hline 1. & Ya & 4 \\
2. & Tidak & 1 \\
\hline
\end{tabular}

Table. 13 Bobot Presentase Kriteria

\begin{tabular}{ccc}
\hline No. & Kriteria (x) & $\begin{array}{c}\text { Bobot Presentase } \\
\text { Kriteria }(\mathrm{W})\end{array}$ \\
\hline 1 & Pendapatan/bln & 0.1 \\
2 & Jumlah Tanggungan & 0.1 \\
3 & Pekerjaan & 0.1 \\
4 & Kepemilikan Rumah & 0.1 \\
5 & Lantai rumah & 0.05 \\
6 & Kepemilikan Kamar Mandi & 0.05 \\
7 & Kepemilikan Lahan & 0.05 \\
8 & Pendidikan KK & 0.05 \\
9 & Terindikasi Covid 19 & 0.15 \\
10 & Terkena PHK & 0.15 \\
\hline
\end{tabular}

c) Tahap berikutnya adalah memastikan masing-masing kriteria apakah tercantum Cost atau Benefit. Berikut Tabel 14 yang menunjukan Cost ataupun Benefit dari masing-masing kriteria.

Table 14. Cost Benefit

\begin{tabular}{ccc}
\hline No & Kriteria (x) & Cost/ Benefit \\
\hline 1 & Pendapatan/bln & Benefit
\end{tabular}




\section{Journal of Computer and Information Systems Ampera}

Vol. 2, No. 1, January 2021 e-ISSN: 2775-2496

https://journal-computing.org/index.php/journal-cisa/index

\begin{tabular}{ccc}
\hline 2 & Jumlah Tanggungan & Benefit \\
3 & Pekerjaan & Benefit \\
4 & Kepemilikan Rumah & Benefit \\
5 & Lantai rumah & Benefit \\
6 & Kepemilikan Kamar Mandi & Benefit \\
7 & Kepemilikan Lahan & Benefit \\
8 & Pendidikan KK & Benefit \\
9 & Terindikasi Covid 19 & Cost \\
10 & Terkena PHK & Cost \\
\hline
\end{tabular}

d) Tahap berikutnya ialah membuat table keputusan. Tabel keputusan merupakan table yang berisi jumlah total dari bobot $n$ per alternatof ialah kepala keluarga. Tabel 15 menunjukan table keputusan yang berisi bobot dari $\mathrm{n} 1$ hingga $\mathrm{n} 10$ buat masing-masing alternatif.

Table 15. Tabel Keputusan

\begin{tabular}{ccccccccccccc}
\hline No & $\begin{array}{c}\text { Alternatif } \\
\text { (Ai) }\end{array}$ & n1 & n2 & n3 & n4 & n5 & n6 & n7 & n8 & n9 & n10 & $\sum \mathbf{n}$ \\
\hline 1 & Sutrisno & 2 & 4 & 2 & 1 & 2 & 1 & 4 & 3 & 4 & 4 & 27 \\
2 & Darwin & 3 & 3 & 3 & 3 & 2 & 1 & 4 & 4 & 4 & 1 & 28 \\
& Peru & & & & & & & & & & & \\
3 & Sardianto & 3 & 5 & 3 & 1 & 4 & 4 & 1 & 5 & 1 & 1 & 28 \\
4 & Muhtarom & 2 & 4 & 2 & 1 & 2 & 1 & 4 & 2 & 4 & 1 & 23 \\
5 & Kasmun & 1 & 3 & 1 & 3 & 1 & 1 & 4 & 1 & 4 & 1 & 20 \\
\hline
\end{tabular}

e) Setelah itu Langkah berikutnya ialah melakukan normalisasi bobot dari tiap kriteria berdasar pada Cost ataupun Benefit jadi rij lalu mengalikan rij dengan bobot presentasi kriteria(W) jadi $C$ n. Serta berikutnya adalah menjumlahkan $\mathrm{Cn}$ dan hasilkan $\mathrm{Vi}$ adalah hasil normalisasi. Dibawah ini merupakan Tabel 16 yang menampilkan hasil akhir normalisasi.

Tabel 16. Akhir Normalisasi

\begin{tabular}{ccc}
\hline No & Alternatif (Ai) & $\boldsymbol{\Sigma} \mathbf{V i}$ \\
\hline 1 & Sutrisno & 0.4425 \\
2 & Darwin Peru & 0.675
\end{tabular}




\section{Journal of Computer and Information Systems Ampera}

Vol. 2, No. 1, January 2021 e-ISSN: 2775-2496

https://journal-computing.org/index.php/journal-cisa/index

\begin{tabular}{lcc}
\hline 3 & Sardianto & 0.785 \\
4 & Muhtarom & 0.54 \\
5 & Kasmun & 0.4985 \\
\hline
\end{tabular}

f) Langkah terakhir yakni mengurutkan masing-masing kriteria berdasarkan pada urutan Vi dari nilai paling tinggi hingga yang terendah. Pada table 17 menunjukan normalisasi akhir yang sudah diurutkan.

Table 17. Normalisasi Akhir Terurut

\begin{tabular}{ccc}
\hline No & Alternatif (Ai) & $\boldsymbol{\Sigma} \mathbf{V i}$ \\
\hline 1 & Sutrisno & 0.4425 \\
2 & Darwin Peru & 0.675 \\
3 & Sardianto & 0.785 \\
4 & Muhtarom & 0.54 \\
5 & Kasmun & 0.4985 \\
\hline
\end{tabular}

\subsection{Desain Sistem}

Tahapan selanjutnya melaksanakan perancangan pemodelan sistem dalam perihal ini periset memakai UML( Unified Modelling Language). UML( Unified Modelling Language) ialah simbol spesial buat menggambarkan bermacam diagram fitur lunak[10]. Pemodelan sistem yang bangun pada sistem pendukung keputusan ini ialah model Use Case Diagram, Class Diagram serta Activity diagram, Berikut peracangan pemodelan sistemnya:

a. Use Case Diagram

Use Case merupakan gambaran dari fungsionalitas yang diharapkan dari sebuah sistem, dan merepresentasikan sebuah interaksi antara aktor dan sistem. Didalam use case terdapat actor yang merupakan sebuah gambaran entitas dari manuasia atau sebuah sistem yang melakukan pekerjaan di sistem. Pada bagian ini actor yang terlibat daam sistem Pendukung Keputusan Penerima Bantuan Covid-19 ini adalah Admin Sebagai administrator yang memanajemen system. 


\section{Journal of Computer and Information Systems Ampera}

Vol. 2, No. 1, January 2021 e-ISSN: 2775-2496

https://journal-computing.org/index.php/journal-cisa/index

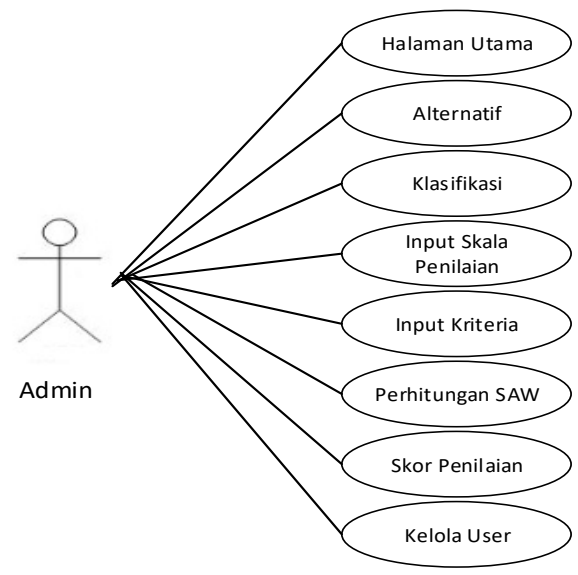

Gambar 2. Use Case Diagram Admin.

b. Activity Diagram

Activity diagram adalah diagram yang menggambarkan sifat dinamis secara alamiah sebuah sistem dalam bentuk model aliran dan kontrol dari aktivitas ke aktivitas lainnya[11]. Activity diagram mengambarkan aliran aktivas dalam system yang sedang dirancang, bagaimana alir berawal, decision yang mungkin terjadi hingga bagaimana mereka berakhir.

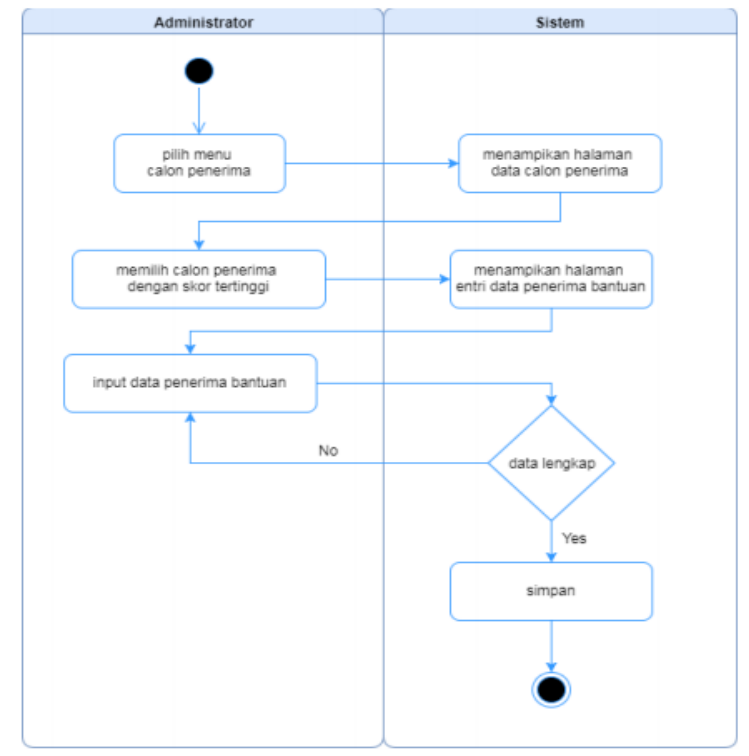

Gambar.3 Activity Diagram Sistem. 


\section{Journal of Computer and Information Systems Ampera}

Vol. 2, No. 1, January 2021 e-ISSN: 2775-2496

https://journal-computing.org/index.php/journal-cisa/index

\section{c. Entity Relationship Diagram Sistem}

Entity Relationship Diagramatau ERD adalah sebuah diagram structural yang digunakan untuk merancang sebuah database[12].

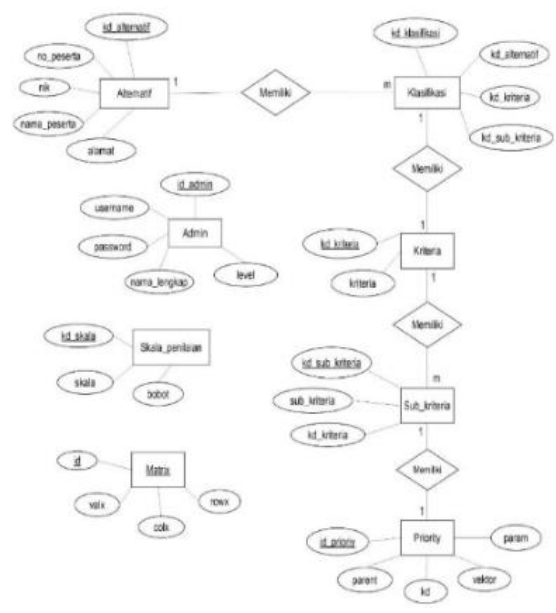

Gambar 4. Entity Relationship Diagram Sistem.

\section{d. Class Diagram Sistem}

Class diagram merupakan gambaran struktur dan deskripsi dari class, package, dan objek yang saling berhubungan[13].

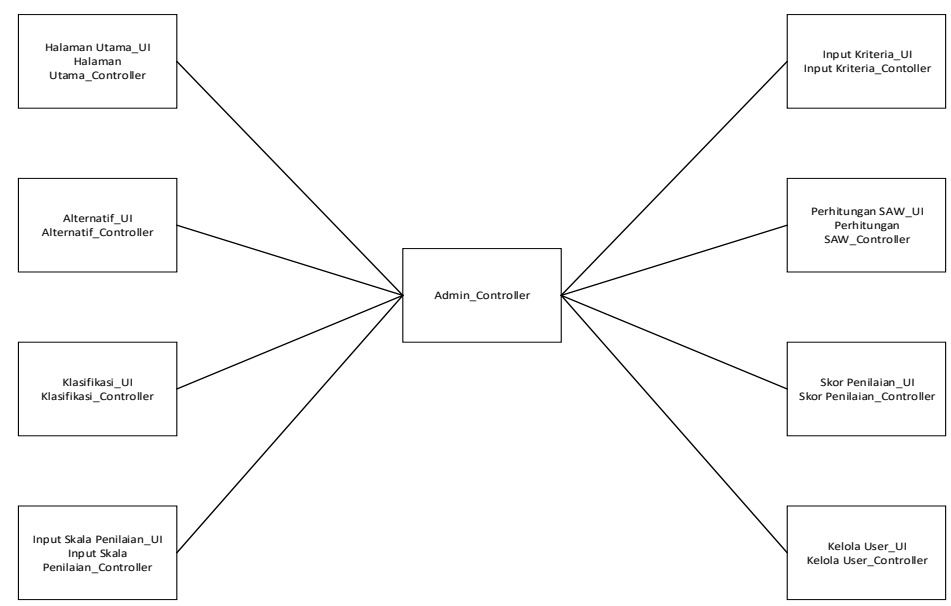

Gambar 5. Class Diagram Sistem. 


\section{Journal of Computer and Information Systems Ampera}

Vol. 2, No. 1, January 2021 e-ISSN: 2775-2496

https://journal-computing.org/index.php/journal-cisa/index

5 Rancangan Layout/User Interface

Perancangan antarmuka digunakan untuk menggambarkan tampilan aplikasi yang dibangun, yaitu berupa rancangan layout. Rancangan ini terdiri dari Rancangan Rancangan Layout Form Login (Gambar 6), Rancangan Layout Form Input Data (Gambar 7) dan Rancangan Layout Halaman Data Calon Penerima Bantuan (Gambar 8).

1. Tampilan Depan Sistem

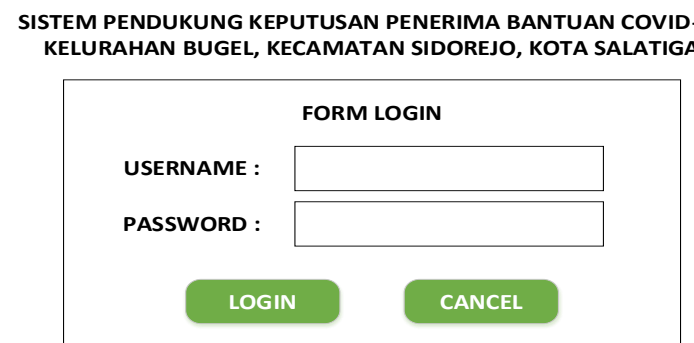

Gambar 6. Form Login

2. Tampilan Input Data

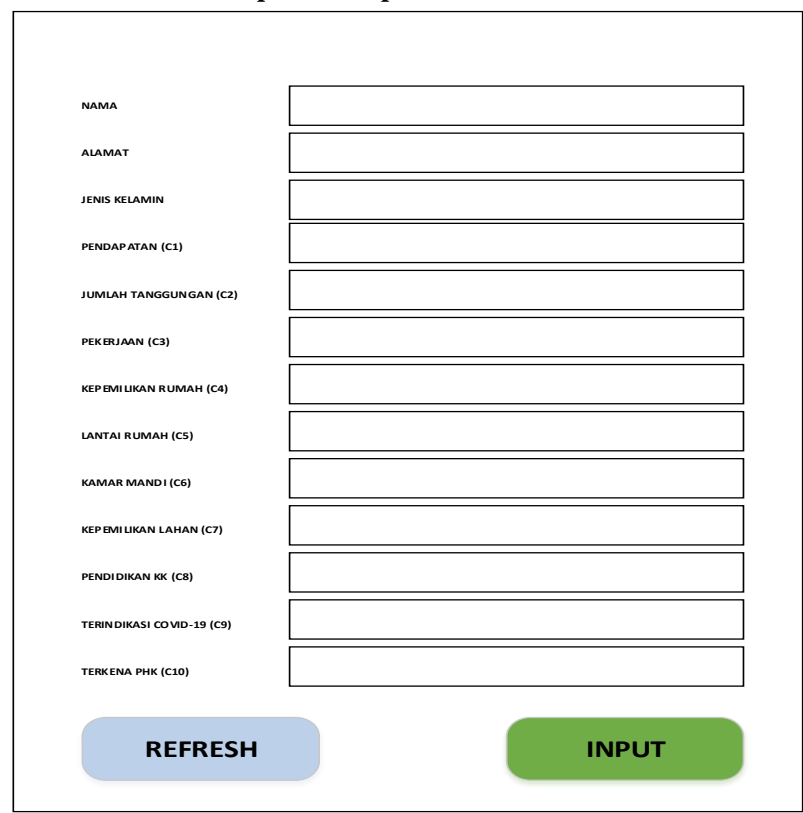

Gambar 7. Form Input Data 


\section{Journal of Computer and Information Systems Ampera}

Vol. 2, No. 1, January 2021 e-ISSN: 2775-2496

https://journal-computing.org/index.php/journal-cisa/index

3. Tampilan Daftar Calon Penerima Bantuan

SISTEM PENDUKUNG KEPUTUSAN PENERIMA BANTUAN COVID-19 KELURAHAN BUGEL, KECAMATAN SIDOREJO, KOTA SALATIGA

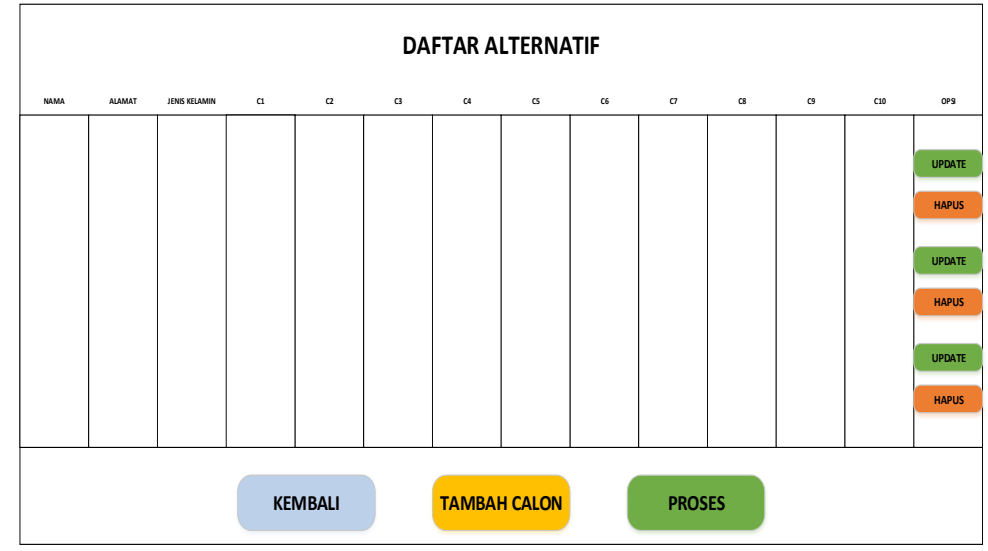

Gambar 8. Halaman Data Calon Penerima Bantuan.

\section{KESIMPULAN}

Berdasarkan penelitian yang ada, dapat ditarik kesimpulan sebagai berikut. Kesimpulan dari penelitian ini adalah Sistem Pendukung Keputusan untuk seleksi menggunakan metode SAW (Simple Addtive Weighthing), yang dapat digunakan sebagai bahan pertimbangan untuk membantu PNS dalam menyeleksi dan menentukan calon penerima. Bantuan Covid-19 diberikan di Kelurahan Bugel sesuai kriteria yang dipersyaratkan format pemeringkatan. Diharapkan penelitian ini dapat digunakan sebagai sarana untuk mengambil keputusan secara cepat dan objektif. Saran untuk penelitian selanjutnya adalah penelitian ini dapat digunakan untuk studi kasus yang berbeda dan lebih bermanfaat. Improvisasi algoritma dan pemilihan algoritma yang lebih baik dapat dilakukan untuk membentuk sistem pendukung keputusan yang lebih baik dan akurat serta untuk mengimplementasikan sistem aplikasi sesuai kebutuhan.

\section{DAFTAR PUSTAKA}

[1] S. A. Weighting and B. L. Tunai, "Dengan Menggunakan Algoritma Simple Additive."

[2] M. A. Salim, "Sistem Pendukung Keputusan Pemilihan Penerima Bantuan Perbaikan Rumah Menggunakan Metode Simple Additive 


\section{Journal of Computer and Information Systems Ampera}

Vol. 2, No. 1, January 2021 e-ISSN: 2775-2496

https://journal-computing.org/index.php/journal-cisa/index

Wieghting (SAW) Studi Kasus Kelurahan Tambelan Sampit Kota Pontianak," J. Sist., vol. 7, no. 2, pp. 120-131, 2018.

[3] J. Sistem, F. Sembiring, M. T. Fauzi, S. Khalifah, and A. K. Khotimah, "Sistem Pendukung Keputusan Penerima Bantuan Covid 19 menggunakan Metode Simple Additive Weighting ( SAW )," vol. 11, no. 2, pp. 97-101, 2020.

[4] P. Non et al., "Sistem Pendukung Keputusan Penerima Bantuan," vol. 17 , no. 2, pp. 200-208, 2020.

[5] A. F. Yulisman1, "Sistem Pendukung Keputusan Penentuan Penerima Bantuan Rumah Sehat Layak Huni Menggunakan Metode Saw Di Desa Pasir Emas Kecamatan Singingi," vol. 12, no. 1, pp. 3950, 2020.

[6] E. Ismanto and N. Effendi, "Sistem Pendukung Keputusan Penerimaan Karyawan Dengan Metode Simple Additive Weighting (SAW)," SATIN - Sains dan Teknol. Inf., vol. 3, no. 1, p. 1, 2017, doi: 10.33372/stn.v3i1.208.

[7] S. Kusumadewi, S. Hartati, A. Harjoko, and R. Wardoyo, "Fuzzy multi-attribute decision making (fuzzy madm)," Yogyakarta Graha Ilmu, pp. 78-79, 2006.

[8] J. Kittur et al., "Evaluating optimal generation using different multicriteria decision making methods," in 2015 International Conference on Circuits, Power and Computing Technologies [ICCPCT-2015], 2015, pp. 1-5.

[9] I. P. Pertiwi, F. Fedinandus, and A. D. Limantara, "Sistem Pendukung Keputusan Penerima Program Keluarga Harapan (PKH) Menggunakan Metode Simple Additive Weighting," CAHAYAtech, vol. 8, no. 2, p. 182, 2019, doi: 10.47047/ct.v8i2.46.

[10] S. Mallu, "Sistem pendukung keputusan penentuan karyawan kontrak menjadi karyawan tetap menggunakan metode topsis," J. Ilm. Teknol. Infomasi Terap., vol. 1, no. 2, 2015.

[11] H. Haviluddin, "Memahami Penggunaan UML (Unified Modelling Language)," 2011.

[12] M. L. A. Latukolan, A. Arwan, and M. T. Ananta, "Pengembangan Sistem Pemetaan Otomatis Entity Relationship Diagram Ke Dalam Database," J. Pengemb. Teknol. Inf. dan Ilmu Komput. e-ISSN, vol. 2548, p. 964X, 2019.

[13] M. T. Prihandoyo, "Unified Modeling Language (UML) Model Untuk Pengembangan Sistem Informasi Akademik Berbasis Web," J. Inform. J. Pengemb. IT, vol. 3, no. 1, pp. 126-129, 2018. 